\title{
Arsenic (III) Removal from Aqueous Water by Indigenous Iron Ore Adsorbent from Balochistan Province of Pakistan
}

\author{
Zulfiqar Ali Bhatti ${ }^{1 a}$, Khadija Qureshi ${ }^{1 \mathrm{~b}}$, Inamullah Bhatti ${ }^{1 \mathrm{c}}$, Raja Fahad Ashraf ${ }^{2}$, \\ Ghulamullah Maitlo ${ }^{3}$
}

RECEIVED ON 13.11.2019, ACCEPTED ON 19.05.2020

\begin{abstract}
The work focuses on the removal of Arsenic-III (As(III)) from water sample by an indigenous iron ore from Balochistan by adsorption method. Three iron ore samples were analyzed by X-Ray Diffractometer (XRD) and a sample from Shikarap containing iron $36.2 \%$ was selected because it contained the highest amount of hematite. The batch study was conducted to examine the adsorption by iron ore and maximum adsorption was observed at pH 6, 1/2 g dose per $50 \mathrm{~mL}$ solution, contact time $2 \mathrm{hr}$ and shaking speed $150 \mathrm{rpm}$. At the optimized conditions, the removal was $89 \%$ when monitored at $50 \mu \mathrm{g} \mathrm{L}^{-1}$ initial concentration of arsenic. The arsenic removal was monitored by Atomic Absorption Spectrometer (AAS) using hydride generation. Dubinin Radushkevich (D-R), Freundlich and Langmuir's isotherms were examined. The highest adsorption capacity of iron ore for As(III) removal was observed $13.67 \mu \mathrm{g} \mathrm{g}^{-1}$ by Langmuir model and Freundlich isotherm indicated good adsorption intensity with value $n=1.512$. Thermodynamic parameters revealed that adsorption was exothermic and physisorption. The Scanning Electron Microscope (SEM) and Energy Dispersive X-Ray (EDX) techniques were applied to scan the surface morphology and the percentage elemental composition of samples respectively. SEM results demonstrated that Shikarap mineral grains are an oval shape and these were changed after the uptake of As(III). The EDX spectra of Shikarap mineral confirm the As(III) adsorption on particles as As $4.19 \%$.
\end{abstract}

Keywords: Arsenic Adsorption, Atomic Absorption Spectrometry, Kinetics, Isotherm, Iron Ore.

\section{INTRODUCTION}

$\mathrm{E}$ lements that have an atomic weight between 63.5-200.6 and possess density greater than 5 $\mathrm{g} / \mathrm{m}^{3}$ are basically described as heavy metals [1-2]. Copper, zinc, manganese, iron, cobalt, are some of the examples of heavy metals and effect on the biochemical processes occurring in the human body. The excessive exposure of the human body with these heavy metal results in hazardous conditions. The other toxic heavy metals include chromium, mercury, lead, cadmium, and arsenic. The concentration of toxic heavy metals even in parts per billion is nondegradable, accumulates in the human body and produce severe health problems [3]. The common techniques applied for the sequestration of heavy metals from water include adsorption, precipitation, ion exchange, membrane separation, coagulation, and flocculation. Fu et. al. [4], Hua et. al. [5] and Barkat et. al. [6], focused on adsorption process for the

${ }^{1}$ Department of Chemical Engineering, Mehran University of Engineering and Technology, Jamshoro, Sindh, Pakistan. Email: azulfiqar.bhatti@ faculty.muet.edu.pk (Corresponding Author).

bkhadija.qureshi@ faculty.muet.edu.pk, cinamullah.bhatti@faculty.muet.edu.pk

${ }^{2}$ Department of Textile Engineering, Mehran University of Engineering and Technology, Jamshoro, Sindh, Pakistan. Email: raja.ashraf@faculty.muet.edu.pk

${ }^{3}$ Department of Chemical Engineering, Dawood University of Engineering and Technology, Karachi, Sindh, Pakistan. Email: metlo2696@yahoo.com

This is an open access article published by Mehran University of Engineering and Technology, Jamshoro under CC BY 4.0 International License. 
removal of contaminants from water. Burakov et. al. [7], did a detailed review on adsorptive removal of heavy metals through conventional as well as through nanostructured materials. From their research it was comprehended that each technique used for the removal of heavy metals and toxic substances has limitations and merits in terms of cost, feasibility, excessive operational time, incompatibility at larger scale operations and secondary pollutants generation during the removal processes.

As is one of the lethal element reported in groundwater from over seventy countries, posing health hazards to about 0.15 billion people worldwide [8-10]. Among these 0.11 billion people live in the south and south Asian countries [11]. The arsenic polluted underground water used for watering of crops may also cause health hazards to people consuming field grown food products, vegetables and fruits [12]. Podgorski et. al. [13] measured the concentration of As in groundwater of Pakistan and estimated that approximately fifty to sixty million people consume subsurface water inside this area are at high risk, with predicament around Lahore, Hyderabad and required appropriate mitigation measures. Shakoor et. al. [14], reported that $53 \%$ groundwater of suburban parts of Punjab, Pakistan indicated exceeding arsenic values than the World Health Organization (WHO) safe limits of $10 \mu \mathrm{g} \mathrm{L}^{-1}$ or ppb. The underground water is contaminated with higher concentration of As that pose serious threat to the health of people. The arsenic concentration of ground water in most parts of the Sindh province is above $20 \mathrm{ppb}$ that makes water unfit for drinking purpose [15]. The groundwater samples (106) from 24 districts of Sindh province of Pakistan were analyzed for arsenic contents and the results indicated that $45 \%$ samples had arsenic above $10 \mathrm{ppb}$ with the highest concentration of $200 \mathrm{ppb}$ of As [16]. Water is the main path by which arsenic enters human organisms. Hence, treatment of arsenic-polluted water with indigenous technologies and supplying the clean water to the public is an important task of the world nowadays. The most commonly used methods for As dealing from water are based on oxidation, coprecipitation followed by adsorption onto coagulated flocks, ion exchange, lime treatment, sorption, membrane filtration, and hybrid methods combined with membrane filtration [17]. Among these technologies, adsorption is considered as frontier protection for the treatment of arsenic from potable water. The selective adsorption utilizes biological materials, mineral oxides, activated carbons or polymer resins [1]. A number of indigenous methods based on adsorption have been developed, such as Kalshi and bucket type units for the removal of arsenic [1]. The elemental iron or iron hydroxides have a high affinity for As (III) and As (V) are extensively used for the removal of arsenic [18-20]. Zero-valent (Fe) powders have been used or added to household filters to remove arsenic from contaminated groundwater [21-22]. There are promising material because of their large surface area, but cannot be applied in a fixed bed column, because these are fine powders and require to be converted to granular material [23]. Hematite (Fe2O3) is known as efficient As removal adsorbent from contaminated water [24-27] as iron oxides can form strong adsorption complexes with an As compound. Researchers examined natural ores as adsorbents for the elimination of As from toxic water [28]. The iron ores containing hematite were reported to be effective for the adsorption of As. The present work examines the utility of indigenous iron ores for the treatment of $\mathrm{As}(\mathrm{III})$ from the water.

\section{MATERIALS AND METHODS}

\subsection{Materials}

The iron ore samples from Balochistan were provided by the Pakistan Geological Survey, from five different locations of province Balochistan which include Quetta, Shikarap, Hoshi, Chagi, Qalat, and Dilband. A huge deposit of 165 million tons of iron ore is reported from Dilband, Balochistan. Iron ores are present in large amounts in Balochistan and Sindh provinces of Pakistan. These are used as raw materials for steel manufacturing in steel mill industries and proved as a cost-effective material for As exclusion from drinking water. Another sample of iron ore was collected from Sonheri formation, Jamshoro. The main iron minerals were $\left(\mathrm{Fe}_{2} \mathrm{O}_{3}\right)$ and Pyrrhotite with iron $(\mathrm{Fe})$ in the range of $7-57.3 \%$ (Table 1). Laboratory grade reagents and chemicals were used during this study. Deionized water was prepared to make all the solutions during the analytical work. As(III) standard solution of 100 ppm concentration was purchased from Inorganic 
venture company, USA.

Stock solutions of concentration $1000 \mu \mathrm{g} \mathrm{L} \mathrm{L}^{-1} \mathrm{As}$ (III) were prepared by mixing the standard solution of 100 ppm As(III) with deionized water. These concentrated solutions were used to make secondary solutions for the experiment in polyethylene bottles and were kept in a dark area to avoid any effect on As concentration. The molar solution of $0.1 \mathrm{M}$ for Sodium hydroxide $(\mathrm{NaOH})$ Millipore Sigma, the United States and 0.1M HCI (Hydrochloric Acid) Millipore Sigma, United States was used for the adjustment of $\mathrm{pH}$. The iron (Fe) standard of 100 ppm concentration was purchased from Inorganic venture company, USA. The stock solution of iron $(\mathrm{Fe})$ was prepared from mingling $(\mathrm{Fe})$ standard solution of 100 ppm using distilled water [2930]. This concentrated solution was utilized to make lower concentration solutions for experiments as per need. The steps involved in the pretreatment of iron ore including crushing, grinding, sieving and washing with deionized water are described in our previous work performed at the Department of Chemical Engineering, Mehran University of Engineering \& Technology), Jamshoro (MUET), Pakistan [31]. The iron ore particle size of $600 \mu \mathrm{m}$ was used in the adsorption experiments. Further acid digestion of mineral ore with Nitric Acid $\left(\mathrm{HNO}_{3}\right)$ and $\mathrm{HCl}$ was performed. In the beginning of acid digestion method $0.5 \mathrm{~g}$ of iron ore samples $(600 \mu \mathrm{m})$ was taken in a conical flask, mixed with $3 \mathrm{~mL}$ nitric acid (HNO3, $>65 \%$ ) and $2 \mathrm{~mL}$ hydrochloric acid $(\mathrm{HCl},>37 \%)$. Agitation and heating were ensured on the magnetic hot plate stirrer (Wise stir, wisd, Korea with the feedback control system and digital timer function). The flask was gently heated and stirred with magnet until the iron ore particles were digested in acid solution. As the sample was slowly heated to dryness, $2 \mathrm{~mL} \mathrm{HCl}$ was added to further digest the iron ore particles completely. Finally, $100 \mathrm{~mL}$ of distilled water was added in the digested sample, filtered and analyzed on atomic absorption spectrometer (AAnalyst 700, Perkin Elmer, USA) for iron (Fe) detection through air-acetylene flame technique at a wavelength of $248.3 \mathrm{~nm}$ [30] as recommended by the manufacturer. As and iron were analyzed by atomic absorption spectrometer in the Department of Chemical Engineering, MUET, Pakistan. A study was conducted by Chatterjee et. al. [32], to remove arsenic up to $90 \%$ by treated iron ore slime doped in polysulfide hollow fiber membrane and the results were confirmed by XRD and SEM.

\subsection{XRD Analysis}

Characterisation of mineralogical composition of iron ores was done using XRD technique [33]. The XRD patterns of crystalline phases were identified by X-ray diffractometer (BRUKER AXS) at Department of Geology, University of Sindh, Jamshoro, Pakistan. The EVA package software was used for the identification of peaks.

\subsection{Sorption Studies}

The adsorption tests of As(III) on iron mineral samples were performed using a batch reactor [21]. Batch adsorption experiments were conducted utilizing 150 $\mathrm{mL}$ Erlenmeyer flask preparing $50 \mathrm{~mL}$ As(III) at required $\mathrm{pH}$ and concentrations. Power of hydrogen $\mathrm{pH}$ investigation was carried out by Microprocessor pH meter. The iron ore adsorbent of particle size 600 $\mu \mathrm{m}$ was introduced in As(III) solution according to the desired quantity and Erlenmeyer flask were shaken on a reciprocating shaker for 2 hours at $150 \mathrm{rpm}$. To isolate the iron mineral particles, the test samples were then filtered. Then the filtered solution was scrutinized by AAS at a wavelength of $193.7 \mathrm{~nm}$ by MHS technique [17,23]. The estimation of $\mathrm{pH}$ was conducted after adsorption tests to monitor the buffering impact. As adsorbed percent was determined by Equation (1).

As $\%=\left[\frac{\left(\mathrm{C}_{\mathrm{i}}-\mathrm{C}_{\mathrm{f}}\right)}{\mathrm{C}_{\mathrm{i}}}\right] \times 100$

where $C_{i}$ represents the initial concentration of As in the solution, $\mathrm{C}_{\mathrm{f}}$ shows the final concentration of residual As. For the reduction of errors and affirmation of results, the tests were repeated $(n=3)$ and the mean results were considered. The replica results deviated within the range of $\pm 5 \%$. After the blank tests, there was no observable As(III) adsorbed on the sidewalls of Erlenmeyer flask.

\subsection{Isothermal Sorption Studies}

To obtain the adsorption capacity of As(III) on hematite and properties of adsorption, the isotherms have an important role. Langmuir, Freundlich, and D- 
$\mathrm{R}$ isotherms were applied to obtain the isotherm constants and the regression coefficient of adsorption experiment analysis [29,31,34]. Isothermal tests were performed by varying As initial concentration from 12.5-500 ppb, maintaining adsorbent quantity $1 / 2 \mathrm{~g}$ constant. Equilibrium time and $\mathrm{pH}$ was kept at 2 hours and 6 , respectively during these tests.

\subsection{Thermodynamic and Kinetic Parameters}

The thermodynamic parameters such as $\Delta \mathrm{S}^{\mathrm{o}}, \Delta \mathrm{G}^{\mathrm{o}}, \Delta \mathrm{H}^{\mathrm{o}}$ are determined and explained thoroughly. Pseudofirst-order kinetic model was applied to assess the kinetic study of $\mathrm{As}(\mathrm{III})$ adsorption on iron ores. Glocheux et. al. [35] found that laterite iron ore is an efficient, low-cost adsorbent for the treatment of As from groundwater by adsorption. The kinetic data was modeled using Pseudo-first and second-order kinetic models and the maximum loading capacity was found $127.8 \mu \mathrm{gg}^{-1}$.

\section{SURFACE CHARACTERIZATION}

\subsection{SEM and EDX Characterization}

The iron ore particles surface morphology (at the beginning and at the end of As adsorption) were examined by SEM (JEOL 6380) [29]. The percentage (\%) elemental configuration was assessed by energy dispersive X-Ray spectroscopy (EDX) (JEOL, JED 2300 Analysis station, Japan) performed at the Department of Metallurgy \& Materials Engineering, Mehran University of Engineering \& Technology, Jamshoro, Pakistan.

\subsection{Specific Surface Area}

The Laser Scattering Particle Size Distribution Analyzer (LA-300, HORIBA, Japan) was used to measure iron ores particle size. The particle size measured for iron ore samples were observed $150 \mu \mathrm{m}$ using laser diffraction analysis technique. The volumetric mass density of $5.150 \mathrm{Kg} \mathrm{m}^{-3} \mathrm{Fe}_{2} \mathrm{O}_{3}$ was applied to figure out the surface area with the assistance of LA-300.

\section{RESULTS AND DISCUSSION}

\subsection{Adsorbent Characterization}

Iron ore samples from Balochistan and Jamshoro were evaluated for iron content using an atomic absorption spectrometer (Table 1). The findings of Iron ( $\mathrm{Fe}$ ) study show that the Chagi sample contains highest $57.3 \%$ of $\mathrm{Fe}$ in iron ore. Chagi particles had a shiny look than other samples. The second highest is the Shikarap with $36.2 \%$ Fe content, while the Sonheri, Jamshoro sample contains the lowest $7 \% \mathrm{Fe}$ among all indigenous iron ore samples of Balochistan and Jamshoro. The iron ores with iron content (29.2-57.3\%) were selected for XRD analysis. The grain size of iron ore specimens analyzed with the laser diffraction was 150 micrometer.

\begin{tabular}{|c|c|c|}
\hline \multicolumn{3}{|c|}{ Table 1: Analysis Of (FE) From Iron Ore through AAS } \\
\hline $\begin{array}{c}\text { Sample } \\
\text { Location }\end{array}$ & Fe (\%) in 1g Ore & Fe (\%) in Ore \\
\hline Shikarap & 0.362 & 36.2 \\
\hline Chagi & 0.57 & 57.3 \\
\hline Dilband & 0.193 & 19.3 \\
\hline Qalat & 0.215 & 21.5 \\
\hline Sonheri, & 0.07 & 7 \\
\hline Jamshoro & 0.29 & 29.2 \\
\hline Hoshi & & \\
\hline
\end{tabular}

\subsection{X-Ray Diffractogram Studies}

Iron ore samples of Hoshi and Shikarap were studied by XRD and the results are shown in Figs. 1-2. Analyzing the XRD outcomes with EVA programming, hematite and quartz compounds were observed from the peaks of Hoshi sample. The peaks observed at $26.5^{\circ}$ on $2 \theta$ are assigned as low quartz. Alternate peaks emerging at $33^{\circ}$ and $35.5^{\circ}$ are discovering the existence of $\left(\mathrm{Fe}_{2} \mathrm{O}_{3}\right)$. The Shikarap ore XRD demonstrates that the peaks are chiefly $\mathrm{Fe}_{2} \mathrm{O}_{3}$. The peaks covering the configuration at $33^{\circ}, 35.5^{\circ}$, $49^{\circ}$, and $54^{\circ}$ are illustrating to $\mathrm{Fe}_{2} \mathrm{O}_{3}$ [29].

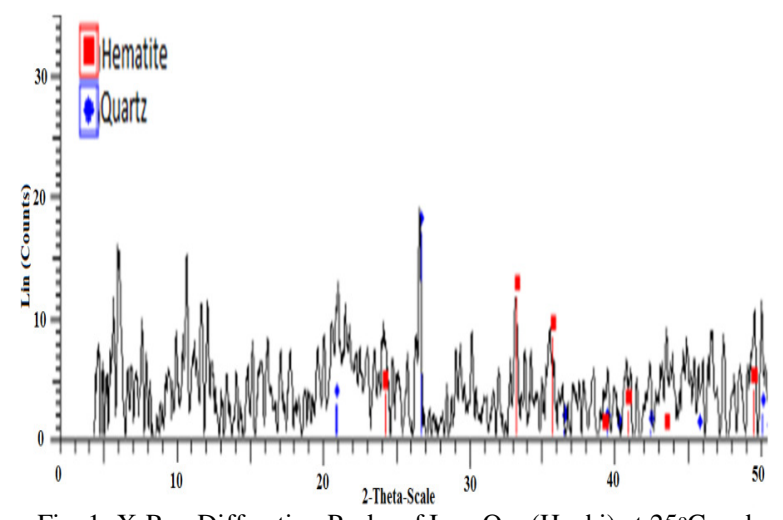

Fig. 1: X-Ray Diffraction Peaks of Iron Ore (Hoshi) at $25^{\circ} \mathrm{C}$ and Sample Weight analyzed $1 \mathrm{~g}$. 


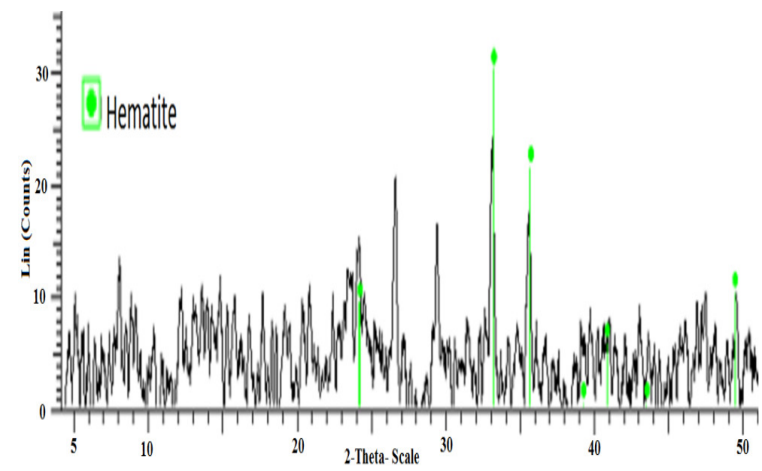

Fig. 2: X-Ray Diffraction Peaks of Iron Ore (Shikarap) at $25^{\circ} \mathrm{C}$ and Sample Weight analyzed $1 \mathrm{~g}$

\subsection{Adsorption Study}

Iron ore from Shikarap was selected for optimization of the parameters i.e. adsorbent dosage, the effect of $\mathrm{pH}$, shaking (contact) time and shaking speed because XRD revealed having the highest quantity of hematite. The adsorption effect of As(III) on other iron ore samples is also observed as presented in Fig. 3.

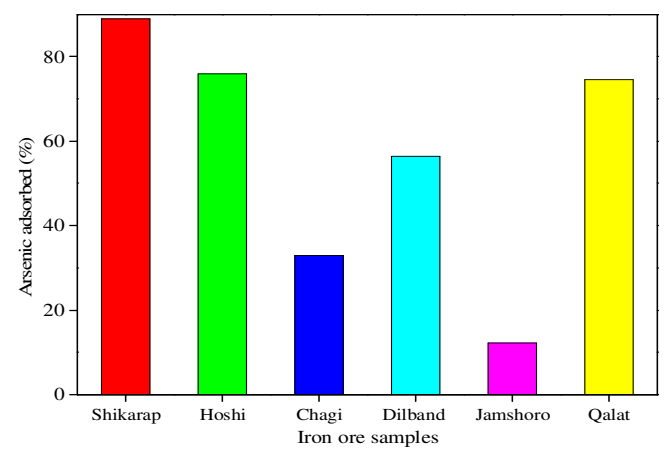

Fig. 3: Adsorption Behavior of Iron Ores (Sorbent Dose 0.5g Per $50 \mathrm{ml}$, pH 6, As (III) Conc. 50 ppb, Shaking Time 2h, RPM 150).

\subsection{Adsorption Behaviour of Iron Ores}

Adsorption of As(III) on different samples of iron ores, i.e. Qalat, Dilband, Hoshi, Jamshoro, Shikarap, and Chagi were analyzed by atomic absorption spectrometer. The adsorption was observed by taking $1 / 2 \mathrm{~g}$ of each iron ore sample per $50 \mathrm{~mL}$ at $\mathrm{pH} 6$, $\mathrm{As}(\mathrm{III})$ concentration of $50 \mathrm{ppb}$ and $2 \mathrm{~h}$ shaking time at $150 \mathrm{rpm}$. The results show that the highest adsorption was by Shikarap iron ore i.e. $89 \%$, followed by Hoshi iron ore i.e. 76\%, and Qalat sample, i.e. 74\%. Shikarap, Hoshi, Qalat, and Dilband showed higher As(III) removal \% because these have higher $\%$ of hematite present in their ores, with the reasonable surface area that provided more adsorption sites available for As(III) which is in relation with a study [26] in which hematite showed good adsorption of As. Chagi iron ore gave 33\% As(III) adsorption though it has high Fe i.e. (57.3\%), this may be because of quartz presence with hematite in it and less surface area i.e. $0.0062 \mathrm{~m}^{2} \mathrm{~g}^{-1}$. A study revealed that quartz samples gave less arsenic adsorption capacity as compared to feldspar. This is because the silonal groups have shown less As removal capacity as compared to aluminol groups [34]. The Jamshoro iron ore shows $12 \% \mathrm{As}(\mathrm{III})$ adsorption, mainly because of Calcite $\left(\mathrm{CaCO}_{3}\right)$ presence along with Pyrrhotite in it and less value of the surface area.

\subsection{Effects of pH on Adsorption of As(III)}

The impact of various $\mathrm{pH}$ ranges from 3-8 on As(III) adsorption is shown in Fig. 4. This was studied to elucidate the impact of solution $\mathrm{pH}$ on adsorption capacity and to set up ideal $\mathrm{pH}$ for adsorption of arsenic in these $\mathrm{pH}$ ranges. The $\mathrm{pH}$ (3-8) impact on the As(III) adsorption by iron oxides was conducted at a concentration of $50 \mathrm{ppb}, 1 / 2 \mathrm{~g}$ of adsorbent mass per $50 \mathrm{~mL}$ and shaking time of $2 \mathrm{~h}$. It is obvious from Fig. 4 that at slightly acidic $\mathrm{pH}$ values $(6<\mathrm{pH}<7), \mathrm{As}(\mathrm{III})$ removal percent, was highest i.e. $89.3 \%$ at $\mathrm{pH}$ 6. This relates to various outcomes in studies $[34,36]$ in which at $\mathrm{pH}$ 6-7 adsorption of As is maximum.

A study [54] reported that, As(III) showed higher removal rates than $\mathrm{As}(\mathrm{V})$ by Zerovalent iron. The $\mathrm{pH}$ effect is generally described by the zero point of charge (ZPC) of the adsorbent. A ZPC of 7.1 has been reported for hematite. Under low $\mathrm{pH}$ conditions, As(III) occurs as neutral $\mathrm{H}_{3} \mathrm{AsO}_{3}$, and the iron oxide undergoes surface protonation. Surface protonation diminishes as the $\mathrm{pH}$ increases to above 5, and approaches 0 at $\mathrm{pH} 7$, resulting in maximum adsorption.

In another study [55] dynamically modified iron coated sand was tested for the removal of As(III). It was observed in this work that adsorption process was $\mathrm{pH}$ dependent and higher As(III) adsorption was achieved in the $\mathrm{pH}$ range (6-8). The researcher in a work [56] concluded that the studied arsenic adsorption densities were changed with $\mathrm{pH}$; in the $\mathrm{pH}$ range 4-10, the maximum removal for As(III) was observed at $\mathrm{pH} 7$ and for $\mathrm{As}(\mathrm{V})$ and $\mathrm{pH}$ 4. The

Mehran University Research Journal of Engineering and Technology, Vol. 40, No. 1, January 2021 [p-ISSN: 0254-7821, e-ISSN: 2413-7219] 
scientists in a work [50] studied adsorption of As(III) by iron oxide coated cement found that $\mathrm{As}(\mathrm{III})$ removal was more with maximum removal $(89.8 \%)$ at $\mathrm{pH}$ 6.7. Other researchers [57] also studied As(III) Adsorption onto Pillared Clays and Iron Oxides. They observed that As(III) adsorption was better at more neutral $\mathrm{pH}$ values $(6<\mathrm{pH}<8)$.

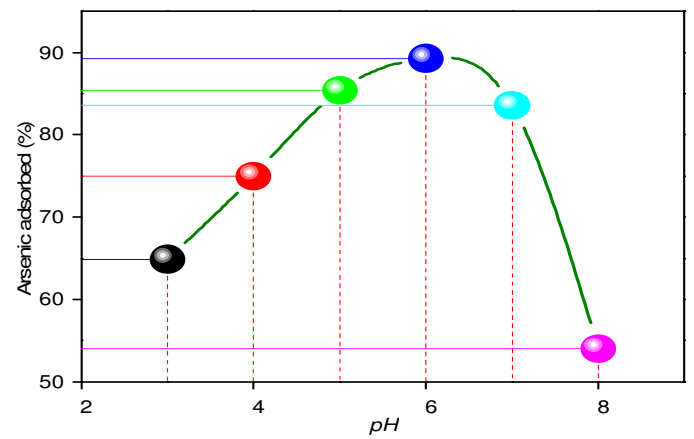

Fig. 4: Effect of ph on Shikarap Iron Ore (Sorbent Dose 0.5g Per $50 \mathrm{ml}$, As (III) Concentration $50 \mathrm{mg} \mathrm{L}^{-1}$, Shaking Time 2h, RPM $150)$.

\subsection{Contact Time Effect on Adsorption}

To discover the viability of adsorption, the mixing time was altered from 1/2-4 hr keeping the remaining parameters constant e.g. $50 \mathrm{ppb}$ of initial As(III) concentration, $6 \mathrm{pH}$ to prepare $50 \mathrm{~mL}$ volume of each test, $1 / 2 \mathrm{~g}$ of adsorbent and shaking velocity of 150 rpm. This is clear from Fig. 5 that As(III) adsorption increases as the contact time rises and the most maximum adsorption is performed at a shaking time of $2 \mathrm{hrs}$. This optimized time is in relation to the studies [34,36], where the researchers also find out the best removal at a contact time of $2 \mathrm{hrs}$. The sorption was quick in the initial hour and a half, ending up more steady state at around $2 \mathrm{hrs}$. As the Shikarap ore surface pores were open in the beginning, the sorption kinetics was fast and controlled by diffusion procedure from the total solution to the outer surface of iron ore [37].

\subsection{Adsorbent Dose Effect}

An adsorbent dose effect was observed by changing the amount from $0.25-1.25 \mathrm{~g}$ per $50 \mathrm{~mL}$ at $\mathrm{pH}$ of 6 with As(III) concentration of $50 \mu \mathrm{g} \mathrm{L}{ }^{-1}$ with $2 \mathrm{~h}$ shaking duration at $150 \mathrm{rpm}$. The As(III) removal \% was enhanced with the rise in adsorbent dosage from 0.25 to $1 / 2 \mathrm{~g}$. The best As(III) removal efficiency of $89 \%$ is at an adsorbent mass of $1 / 2 \mathrm{~g}$ as demonstrated in Fig. 6 . The results obtained regarding adsorption dose were found in good agreement $(0.1-2 \mathrm{~g})$ with the previous study done by the researcher [38]. Thus, an adsorbent mass of $1 / 2 \mathrm{~g}$ was optimized for further tests.

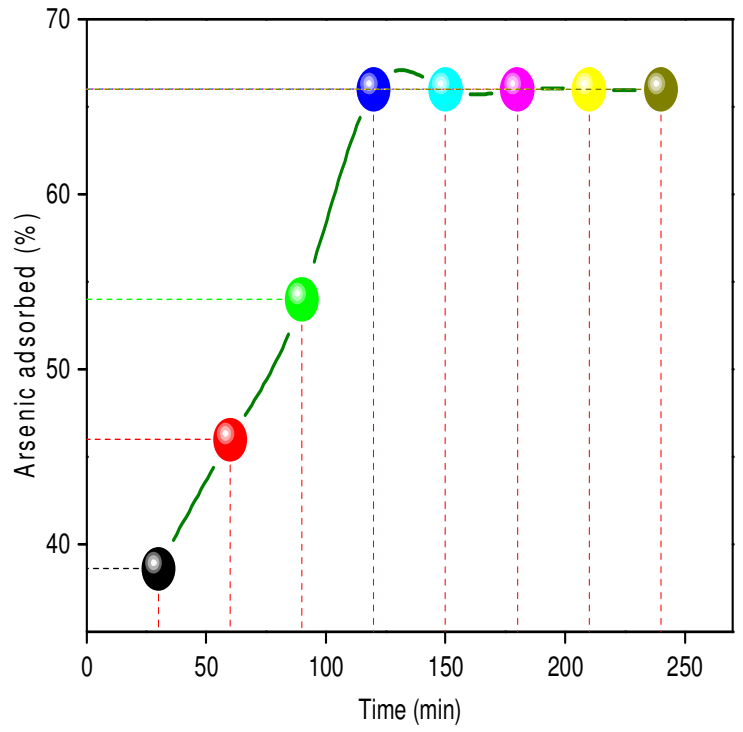

Fig. 5: Mixing Time Effect on As(III) Adsorption (Adsorbent $0.5 \mathrm{~g}$ per 50ml, As(III) Concentration 50 ppb, ph 6, RPM 150).

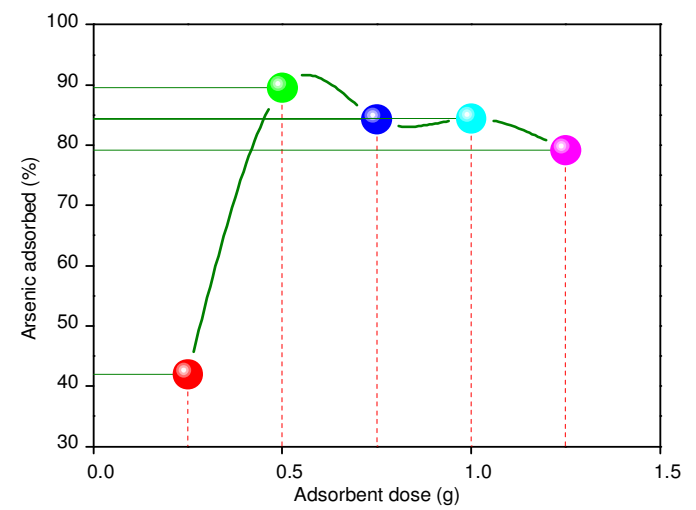

Fig. 6: Adsorbent Dose Effect on As (III) Removal (pH 6, As (III) Concentration 50 ppb, Shaking Time 2 Hrs, RPM 150).

\subsection{Shaking Speed Effect}

Different shaking velocities were selected for the adsorption of Shikarap ore samples keeping $\mathrm{pH}$ unchanged at 6 . The agitation velocity was changed from 75-200 rpm. The concentration of arsenic was 50 $\mathrm{ppb}$ in beginning for the preparation of $50 \mathrm{ml}$ volume using $1 / 2 \mathrm{~g}$ of $\left(\mathrm{Fe}_{2} \mathrm{O}_{3}\right)$ as an adsorbent. In the first instance, the rise in uptake capacity was detected up to $150 \mathrm{rpm}$ and after that, there was about $21 \%$ reduction Mehran University Research Journal of Engineering and Technology, Vol. 40, No. 1, January 2021 [p-ISSN: 0254-7821, e-ISSN: 2413-7219] 
in uptake capacity while achieving $200 \mathrm{rpm}$ as appeared in Fig. 7. In this way, the shaking rate of 150 rpm was set best for further tests.

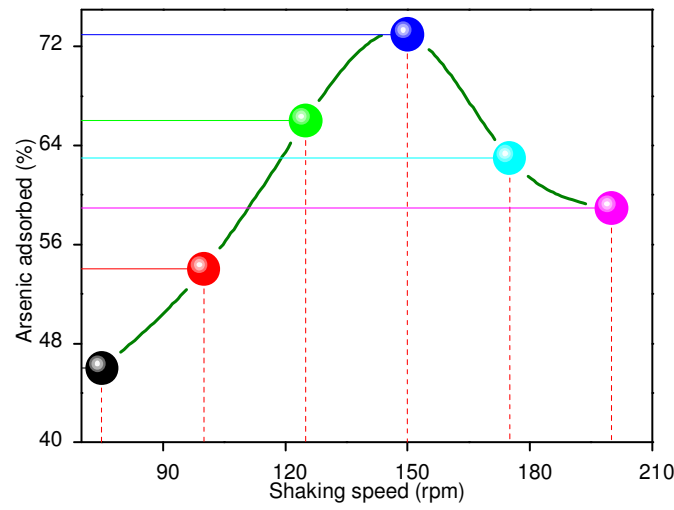

Fig. 7: Effect of Shaking Speed (rpm) on the Arsenic Adsorbed \% by Shikarap Iron Ore, (Sorbent Dose $0.5 \mathrm{~g}$ Per $50 \mathrm{ml}$, As(III) Concentration $50 \mathrm{ppb}, \mathrm{pH}$ 6, Shaking Time 2h).

\subsection{Adsorption Isotherm}

The Langmuir isotherm adsorption in Equation (2) was used to demonstrate the equilibrium information.

$$
\frac{1}{\mathrm{q}_{\mathrm{e}}}=\frac{1}{\mathrm{BQ}_{0} \mathrm{C}_{\mathrm{e}}}+\frac{1}{\mathrm{Q}_{0}}
$$

where $\mathrm{Q}_{0}$ is Langmuir constant showing the maximum capacity of monolayer adsorption in $\quad\left(\mu \mathrm{g} \mathrm{g}^{-1}\right), \mathrm{b}$ shows binding energy concerning the process of sorption, whereas $\mathrm{C}_{\mathrm{e}}$ represents the concentration of solute in equilibrium, $\mathrm{Q}_{\mathrm{e}}$ is absorbed the amount of solute of As(III) during equilibrium (mg/g) [25].

The slope and intercept of the linear plot of 1/qe versus 1/Ce (Fig. 8) produced the values of the Langmuir constants $\mathrm{b}$ and $\mathrm{Q}_{0}$ and the same are presented in Table. 2.

Through equating Langmuir parameter $\mathrm{b}$ from the dimensionless separation factor $\mathrm{R}_{\mathrm{L}}$ [30-31], as demonstrated in the subsequent Equation (3), the proclivity between $\left(\mathrm{Fe}_{2} \mathrm{O}_{3}\right)$ adsorbent and $\mathrm{As}$ (III) was determined.

$$
\mathrm{R}_{\mathrm{L}}=\frac{1}{1+\mathrm{bC}_{0}}
$$

where $\mathrm{b}$ is constant of Langmuir isotherm and $\mathrm{C}_{\mathrm{o}}$ represents the $\mathrm{As}(\mathrm{III})$ concentration at the beginning. The analysts [25, 31] observed that by utilizing mathematical equations the $\mathrm{R}_{\mathrm{L}}$ demonstrates the configuration of the isotherm. $\mathrm{R}_{\mathrm{L}}<1$ represents the feasible adsorption and if the result of $R_{L}>1$ then it suggests the infeasible adsorption. The values of $\mathrm{R}_{\mathrm{L}}$ are in the middle of 0 and 1 as presented in Fig. 9 which demonstrate feasible adsorption of As(III) on $\left(\mathrm{Fe}_{2} \mathrm{O}_{3}\right)$ adsorbent.

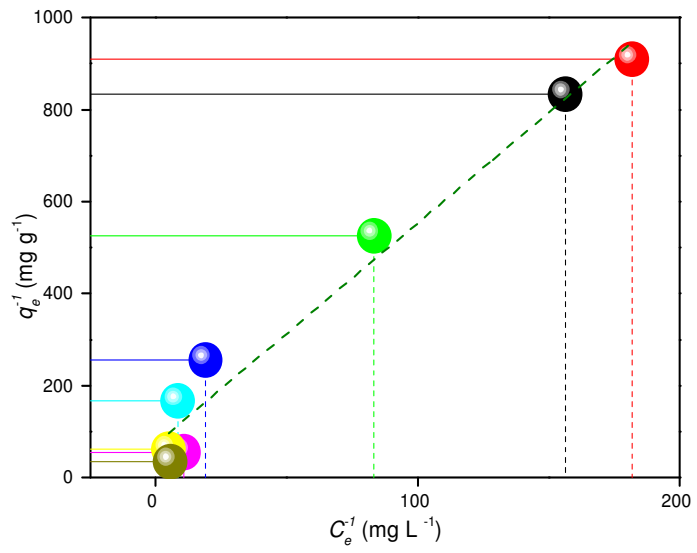

Fig. 8: Langmuir Isotherm (Adsorbent Dose $0.5 \mathrm{~g}$ Per $50 \mathrm{ml}$, pH 6 , Shaking Time $2 \mathrm{hrs}$, Temperature $25 \pm 2^{\circ} \mathrm{C}$, at different As(III) Concentrations with Shikarap Iron Ore)

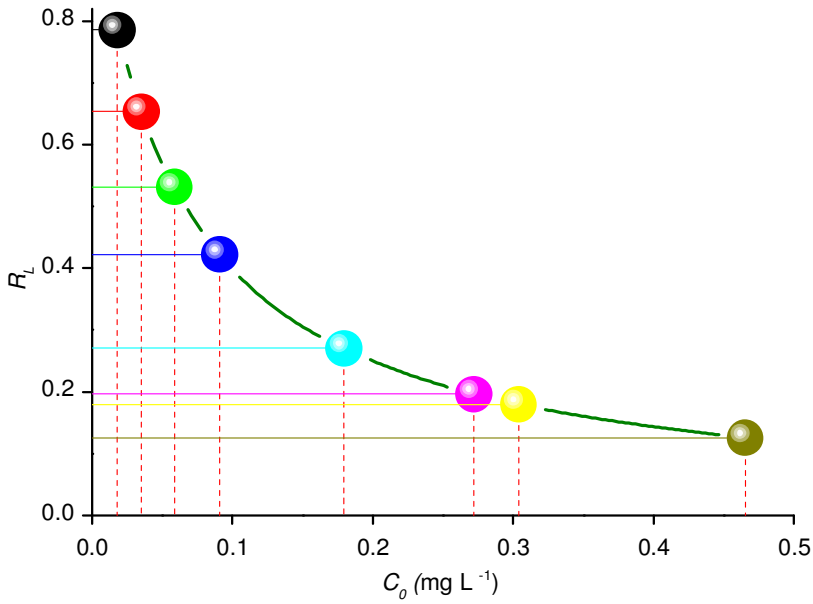

Fig. 9: The Adsorbed Separation Factor of As (III) on Shikarap Ore (Adsorbent Dose 0.5 g Per $50 \mathrm{ml}$, pH 6, Shaking Time 2hrs, Temp: $\left.25 \pm 2{ }^{\circ} \mathrm{C}\right)$.

According the results presented in Table 2, the data fitted reasonably well with the Langmuir isotherm in the adsorption studies carried out. Highly significant regression curve $(\mathrm{R}=0.98)$ was also obtained from Langmuir model.

As indicated by Freundlich isotherm that on heterogeneous surfaces the adsorption of metallic particles occurs and is given in Equation (4). 


$$
\ln \mathrm{q}_{\mathrm{e}}=\operatorname{lin} \mathrm{k}_{\mathrm{k}}+\frac{1}{\mathrm{n}} \ln \mathrm{C}_{\mathrm{e}}
$$

The value of $1 / \mathrm{n}$ and the $y$-intercept is the natural $\log$ of $\mathrm{k}_{\mathrm{f}}$, obtained from the graph showing linearity of slope between $\ln \mathrm{q}_{\mathrm{e}}$ and $\ln \mathrm{C}_{\mathrm{e}}$

At the entire values of As(III) concentration analyzed, the optimum adsorption by $\left(\mathrm{Fe}_{2} \mathrm{O}_{3}\right)$ is explained through a higher value of $n$. The sorption results of $k_{f}$ and $1 / \mathrm{n}$ are well satisfied and given in Table 2.

The linearity graph between $\ln \mathrm{C}_{\mathrm{e}}$ and $\ln \mathrm{q}_{\mathrm{e}}$ yields a slope that is the value of $1 / n$, and the $y$-intercept is the natural $\log$ of $\mathrm{k}_{\mathrm{f}}$ as demonstrated in Fig. 10. Feasible adsorption by $\left(\mathrm{Fe}_{2} \mathrm{O}_{3}\right)$ adsorbent is demonstrated by a higher value of $n$ at the entire values of $\mathrm{As}(\mathrm{III})$ concentrations tested. In Table 2 , the results of $\mathrm{k}_{\mathrm{f}}$ and $1 / \mathrm{n}$ exhibit that the sorption data is well satisfied and these values indicate the capacity and intensity of sorption, respectively. The experimental model has confirmed to be persistent with exponential dissemination of active pores, distinctive of heterogeneous surfaces [22].

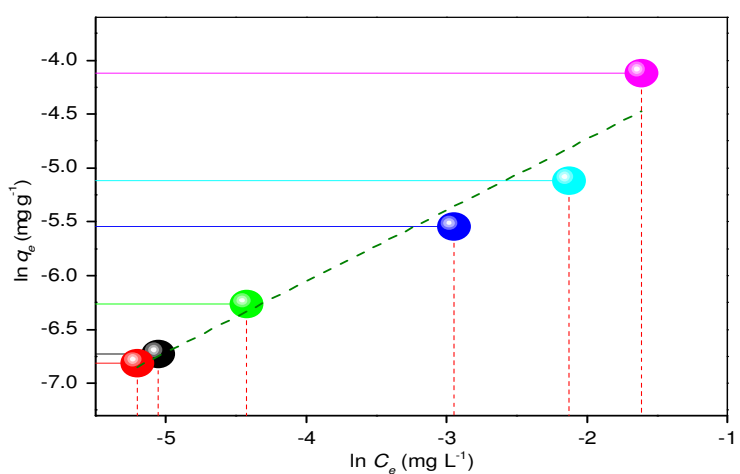

Fig. 10: Freundlich Isotherm Indicating the plot of LN (CE) against LN (QE) (Adsorbent Dose $0.5 \mathrm{~g}$ Per $50 \mathrm{ml}$, pH 6, Shaking Time 2h, Temp: $25 \pm 2{ }^{\circ} \mathrm{C}$, at various initial As (III) Concentrations with Shikarap Iron Ore)

The D-R model is described in Equation (5).

$\ln \mathrm{q}_{\mathrm{e}}=\ln \mathrm{Q}_{\mathrm{m}}-\mathrm{k} \varepsilon^{2}$

where $Q_{m}$ signifies the saturation capacity theoretically, in $\mu \mathrm{g} \mathrm{g}^{-1}$, here $\mathrm{k}$ is constant and shows mean energy in $\left(\mathrm{mol}^{2} \mathrm{k} \mathrm{J}{ }^{-2}\right), \varepsilon$ represents Polanyi potential [RT $\ln (1+1 / \mathrm{Ce})]$, $\mathrm{R}$ shows the universal gas constant, $\mathrm{kJ} \mathrm{mol}^{-1} \mathrm{~K}^{-1}$ and $\mathrm{T}$ represents the temperature in $\mathrm{K}[24,34,50]$.

\begin{tabular}{|c|c|c|c|c|c|c|}
\hline Parameters & Value & $\mathrm{R}$ & Capacity & $\mathrm{pH}$ & $\begin{array}{c}\text { Temperature } \\
\left({ }^{\circ} \mathrm{C}\right)\end{array}$ & Reference \\
\hline \multicolumn{3}{|c|}{ Langmuir Isotherm } & \multirow{10}{*}{$13.66 \mu \mathrm{g} \mathrm{g}^{-1}$} & \multirow{10}{*}{6} & \multirow{10}{*}{25} & \multirow{10}{*}{ This Study } \\
\hline $\mathrm{Q}_{0}\left(\mu \mathrm{g} \mathrm{g}^{-1}\right)$ & 13.668 & \multirow{2}{*}{0.98} & & & & \\
\hline $\mathrm{b}$ & 0.015 & & & & & \\
\hline \multicolumn{3}{|c|}{ Freundlich Isotherm } & & & & \\
\hline $\mathrm{k}_{\mathrm{f}}\left(\mu \mathrm{g} \mathrm{g}^{-1}\right)$ & 0.033 & \multirow{2}{*}{0.97} & & & & \\
\hline $\mathrm{N}$ & 1.512 & & & & & \\
\hline \multicolumn{3}{|c|}{ (D-R) Isotherm } & & & & \\
\hline $\mathrm{Q}_{\mathrm{m}}\left(\mu \mathrm{g} \mathrm{g}^{-1}\right)$ & 0.0128 & \multirow{3}{*}{0.95} & & & & \\
\hline $\mathrm{k}\left(\mathrm{mol}^{2} \mathrm{KJ}^{-2}\right)$ & 0.0151 & & & & & \\
\hline $\mathrm{E}(\mathrm{KJ} / \mathrm{mol})$ & 5.75 & & & & & \\
\hline \multicolumn{2}{|c|}{ Langmuir isotherm } & & $6 \mu \mathrm{g} \mathrm{g}^{-1}$ & 7.5 & 27 & $\begin{array}{c}\text { Mohan and } \\
\text { Pittman [40] }\end{array}$ \\
\hline \multicolumn{2}{|c|}{ Langmuir isotherm } & & $4 \mu \mathrm{g} \mathrm{g}^{-1}$ & 4 & 22 & $\begin{array}{c}\text { Elizalde- } \\
\text { Gonz'alez, et al. } \\
\text { [44] }\end{array}$ \\
\hline \multicolumn{2}{|c|}{ Langmuir isotherm } & & $2 \mu \mathrm{g} \mathrm{g}^{-1}$ & 4 & 22 & $\begin{array}{c}\text { Elizalde- } \\
\text { Gonz'alez, et al. } \\
\text { [45] }\end{array}$ \\
\hline \multicolumn{2}{|c|}{ Langmuir isotherm } & & $1 \mu \mathrm{g} \mathrm{g}^{-1}$ & 4 & 22 & $\mathrm{Xu}$ et al. [46] \\
\hline \multicolumn{2}{|c|}{ Langmuir isotherm } & & $1 \mu \mathrm{g} \mathrm{g}^{-1}$ & 3.5 & 25 & Mohan et al. [47] \\
\hline \multicolumn{2}{|c|}{ Freundlich isotherm } & & $8 \mu \mathrm{g} \mathrm{g}^{-1}$ & 7.6 & 22 & $\begin{array}{c}\text { hirunavukkarasu } \\
\text { et al. }[48]\end{array}$ \\
\hline \multicolumn{2}{|c|}{ Langmuir isotherm } & & $28 \mu \mathrm{g} \mathrm{g}^{-1}$ & 7.5 & 27 & $\begin{array}{c}\text { Mohan and } \\
\text { Pittman [40] }\end{array}$ \\
\hline \multicolumn{2}{|c|}{ Freundlich isotherm } & & $4 \mu \mathrm{g} \mathrm{g}^{-1}$ & 7 & 24 & $\begin{array}{l}\text { Badruzzaman } \\
\text { et al. }[49]\end{array}$ \\
\hline
\end{tabular}


The $\mathrm{k}$ is acquired by the slope between $\ln \mathrm{q}_{\mathrm{e}}$ versus $\varepsilon$ and $\mathrm{Q}_{\mathrm{m}}$ is achieved from the intercept as exhibited in Fig. 11. Fig. 11 shows the plot of $\ln \mathrm{q}_{\mathrm{e}}$ versus $\varepsilon^{2}$ for adsorption on $\left(\mathrm{Fe}_{2} \mathrm{O}_{3}\right)$ ore is not linear totally. Various parameters are showing the behavior of the continuous adsorption procedure. The $\mathrm{E}$ is calculated as 5.75 $\mathrm{kJ} / \mathrm{mol}$ as demonstrated in Table 2. As per previous research was done by Das et al. mean sorption energy in the range $1-8 \mathrm{~kJ} / \mathrm{mol}$ falls into the category of physical adsorption, the mean sorption energy

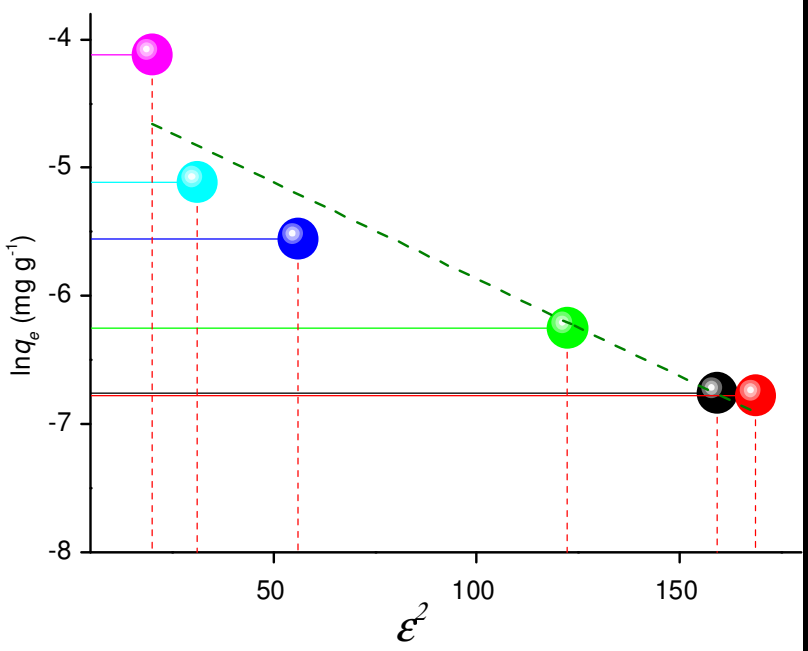

Fig. 11: Dubinin- Radushkevich (D-R) Adsorption Isotherm (Adsorbent Dose $0.5 \mathrm{~g}$ per $50 \mathrm{ml}$, pH 6, Shaking Time 2hrs, Temp: $25 \pm 2{ }^{\circ} \mathrm{C}$, at various initial As (III) Concentrations with Shikarap Iron Ore)

Above 9-16 kJ/mol is termed as chemical adsorption. The activation energy estimated in this study was observed in the range of 1 to $8 \mathrm{~kJ} / \mathrm{mol}$ and was in physical adsorption category [39].

\subsection{Kinetics of As(III) adsorption on iron ore}

Adsorption rate has proved as a vital procedure to study the adsorption method. To equate the adsorption kinetics, hematite adsorbent is equilibrated with 50 $\mathrm{mL}$ of $70 \mathrm{ppb}$ of As for 0-210 min at an interim of half an hour. As demonstrated in Fig. 12, the adsorption uptake of As(III) rises in the early $1.5 \mathrm{hr}$ and then equilibrium state was attained. In Equations (6-7) the Pseudo $1^{\text {st }}$ order kinetic model was used to fit the experimental result data.

$$
\begin{aligned}
& \frac{\mathrm{dq}_{\mathrm{eq}}}{\mathrm{dt}}=\mathrm{k}_{1}\left(\mathrm{q}_{\mathrm{eq}}-\mathrm{q}_{\mathrm{t}}\right) \\
& \log \left(\mathrm{q}_{\mathrm{eq}}-\mathrm{q}_{\mathrm{t}}\right)=\lg \mathrm{q}_{\mathrm{eq}}-\frac{\mathrm{k}_{1} \mathrm{t}}{2.303}
\end{aligned}
$$

The rate constant of pseudo $1^{\text {st }}$ order is represented by $\mathrm{k}_{1}$ and at time $\mathrm{t}, \mathrm{q}_{\mathrm{t}}$, shows the limit of adsorption in $\mathrm{mg} / \mathrm{g}, \mathrm{q}_{\mathrm{t}}$ is the limit of adsorption at time, $\mathrm{t}, \mathrm{k}_{1}$ and correlation coefficients were obtained from linear plots of $\log \left(\mathrm{q}_{\mathrm{eq}}-\mathrm{q}_{\mathrm{t}}\right)$ versus $\mathrm{t}$ as presented in Fig. 13 and exhibited in Table 3. Hematite ore in this section of the work shows a comparatively lower capacity in $\mathrm{mg} \mathrm{g}^{-1}$ since lower initial As(III) concentration of 70 ppb was taken in these tests [41-42].

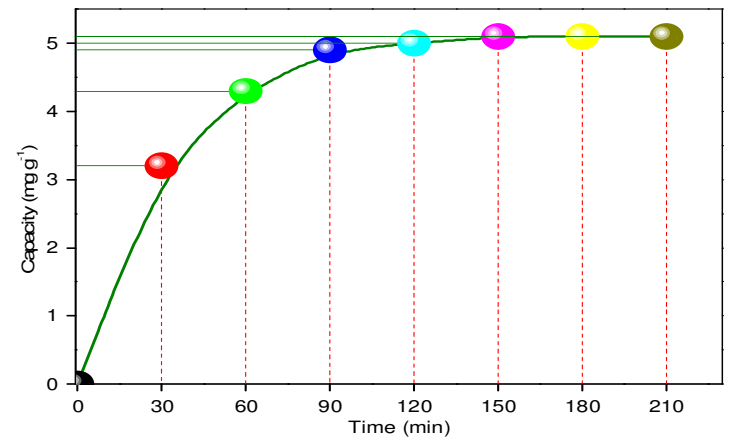

Fig. 12: Adsorption Kinetics of As(III) (Adsorbent Dose $0.5 \mathrm{~g}$ Per $50 \mathrm{ml}$, pH 6, Range of Reaction Time 0-210 Min, Temp: $25 \pm 2^{\circ} \mathrm{C}$, As (III) Concentration $70 \mathrm{mg} \mathrm{L}^{-1}$ )

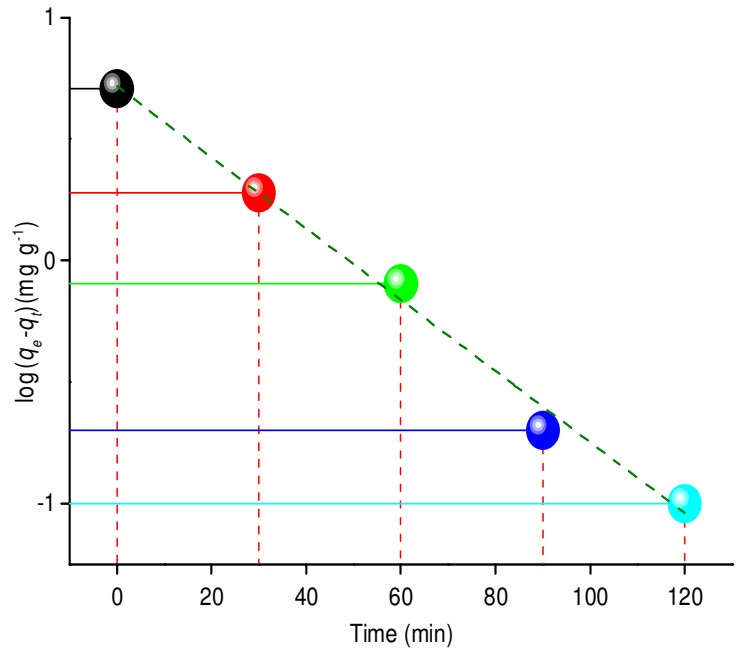

Fig. 13: Pseudo First Order

\begin{tabular}{|c|c|c|}
\hline \multicolumn{3}{|c|}{ Table 3: Model - Pseudo-First-Order } \\
\hline $\mathrm{k}_{1} / \mathrm{min}^{-1}$ & $\mathrm{q}_{\mathrm{eq}} / \mathrm{cal} \mathrm{mg} \mathrm{g}^{-1}$ & $\mathrm{r}^{2}$ \\
\hline 0.033624 & 0.005208 & 0.992 \\
\hline
\end{tabular}

\subsection{Morphological and Elemental Analysis}

Fig. 14(a) shows the SEM picture of Shikarap ore particles before the adsorption of As(III). The SEM figure demonstrates that Shikarap mineral grains are an oval shape. The EDX graph in Fig. 14(b) exhibits the atomic organization of $\left(\mathrm{Fe}_{2} \mathrm{O}_{3}\right)$ compound as; Iron 
(Fe) $45 \%$, Silica (Si) 14\%, Aluminum (Al) $1 \%$ and Oxygen (O) $40 \%$ by mass. The surface morphology of Shikarap mineral grains changed after the uptake of As(III) as illustrated in Fig. 15(a). The EDX spectra in Fig. 15(b) of Shikarap mineral affirm the As(III) adsorption on particles as As $4.19 \%$, whereas Iron $(\mathrm{Fe})$ 43.39\%, Silica ( $\mathrm{Si}) 15.16 \%$ and Oxygen $(\mathrm{O}) 37.26 \%$ by mass. The EDX analysis verified the As(III) adsorption on Shikarap mineral particles and justify the quantitative analysis AAS.

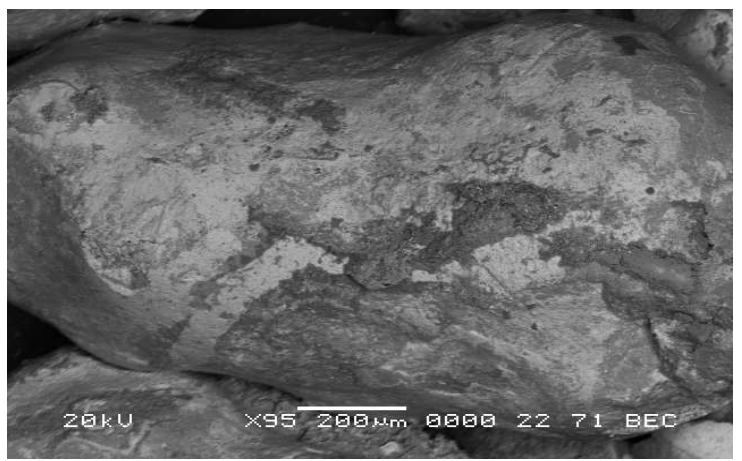

Fig. 14(a): Morphological results of Shikarap Iron Ore before Adsorption

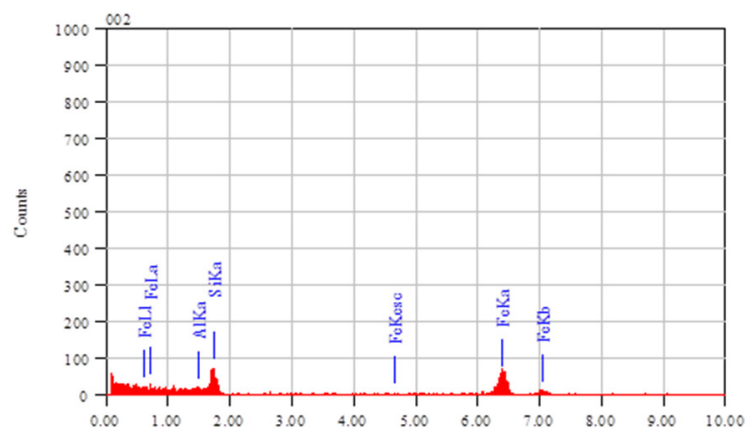

Fig. 14(b): Elemental results of Shikarap Iron Ore before Adsorption

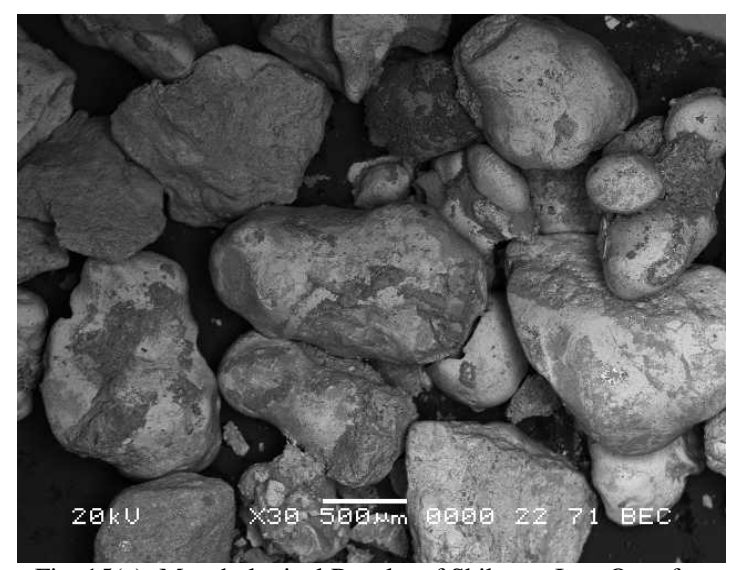

Fig. 15(a): Morphological Results of Shikarap Iron Ore after Adsorption

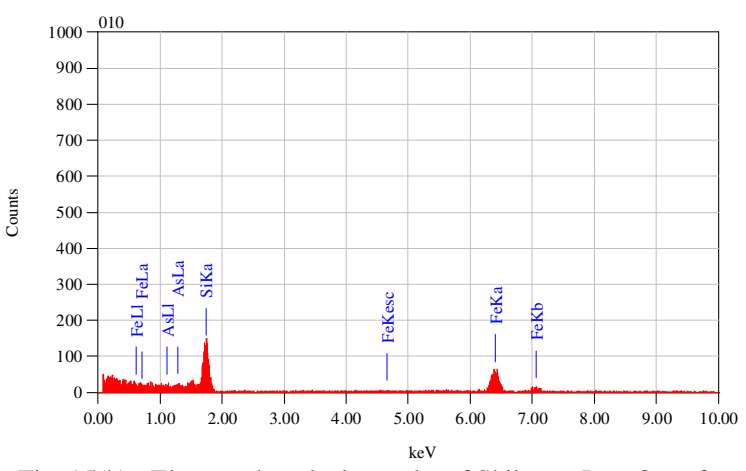

Fig. 15(b): Elemental analysis results of Shikarap Iron Ore after Adsorption.

\section{SPECIFIC SURFACE AREA}

Table 4 is showing the specific surface area of hematite particles. The laser diffraction analysis is based on the theory that the majority of the particles are having smooth permeable pellets. However, actually, hematite particles do not-have consistent shapes containing roughness and irregular surface. The irregular morphology and rough texture can be the cause of the elevated specific surface area of the particles. Throughout the study on equipment, the hematite particles were supposed to be segregated to obtain the suspension of the particles [43].

\begin{tabular}{|c|c|c|}
\hline \multicolumn{3}{|c|}{ Table 4: Specific Surface Area of Iron Ore } \\
\hline Sample & $\begin{array}{c}\text { Specific Surface Area, } \\
\mathrm{m}^{2} \mathrm{~g}^{-1}\end{array}$ & $\begin{array}{c}\text { Arsenic Adsorbed } \\
(\%) \\
\text { Adsorbent } 0.5 \\
\text { gm/50ml }\end{array}$ \\
\hline Shikarap & 0.5275 & 89 \\
\hline Hoshi & 0.0509 & 76 \\
\hline Chagi & 0.0062 & 33 \\
\hline Dilband & 0.3209 & 58 \\
\hline Qalat & 0.2272 & 74 \\
\hline $\begin{array}{c}\text { Sonheri, } \\
\text { Jamshoro }\end{array}$ & 0.1424 & 12 \\
\hline
\end{tabular}

\section{IRON-ARSENITE ADSORPTION MECHANISM}

Iron oxide adsorbents were found more effective in removing arsenic from variety of source waters. Arsenic compounds are known to form strong chemical adsorption complexes with a wide range of $\mathrm{Fe}$ (III) oxides. The basic structural unit of ferric hydroxides is $\mathrm{Fe}^{3+}$ coordinated to 6 oxygen atoms which is depicted in Fig. 16(a). These structural units have a stoichiometry given by $\mathrm{Fe}_{2} \mathrm{O}_{10} \mathrm{H}_{14}$ and are shaped liked octahedra illustrated in Fig. 16(b). These 
octahedral structures combine to outline diverse number of polymeric structures such as ferrihydrite, goethite and lepidocrocite [51-52].

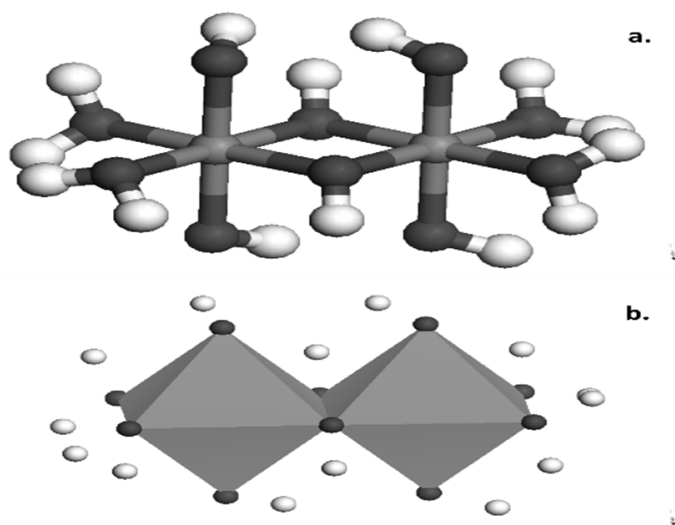

$\mathrm{AL}(\mathrm{OH})_{3}$ have similar structures. Atomic Illustration: Fe-Grey; O-Black; H-White [53] Fig. 16a). Shows Di-Octahedral Unit Cell of FE $(\mathrm{OH})_{3}$ Precipitates (B) $2\left(\mathrm{FE}^{3+}\right)$ Atoms were Octahedrally attached with $6\left(\mathrm{O}_{2}\right)$ Atoms.

\section{CONCLUSIONS}

In this work indigenous Shikarap iron ore was effectively used for the removal of As(III) from water by the batch adsorption method. The iron $(\mathrm{Fe})$ in the indigenous ores was in the range of 7-57.3\%. XRD of iron ore samples showed the presence of Hematite $\left(\mathrm{Fe}_{2} \mathrm{O}_{3}\right)$, Quartz $\left(\mathrm{SiO}_{2}\right)$ in Hoshi and Shikarap, a mixture of hematite and minute quantity of quartz in Chagi. The iron ore samples contained good iron percentage proving these ores are potential adsorbents for the treatment of deadly arsenic-contaminated water. The adsorbent dose study demonstrated that the maximum removal of As(III) was $89 \%$ at the adsorbent dose of $0.5 \mathrm{~g}$ and the optimum $\mathrm{pH}$ for As(III) was 6. The most favorable contact time and shaking speed for As(III) adsorption was 2 hours and $150 \mathrm{rpm}$ respectively. Three isotherms i.e. D-R, Freundlich and Langmuir were studied and the results represented a good fit with the Langmuir model. The particle size homogeneity was observed by Laser diffraction technique, and it was concluded that the structures of the iron ore particles impact the specific surface area. The SEM and EDX results also confirm the As(III) adsorption. Simulation and modeling work to be carried out using Aspen HYSYS by the data generated in this study to design arsenic treatment filters. In the future, the work should be done to fabricate economical/cheap arsenic treatment filters containing indigenous iron ore adsorbents for common people in arsenic affected areas.

\section{NOMENCLATURE}

\begin{tabular}{|c|c|}
\hline As & Arsenic \\
\hline EDX & Energy Dispersive X-Ray \\
\hline SEM & Scanning Electron Microscope \\
\hline As(III) & Arsenic (III) \\
\hline AAS & Atomic Absorption Spectrometer \\
\hline XRD & X-Ray Diffractometer \\
\hline D-R & Dubinin - Radushkevich \\
\hline rpm & Revolution per minute \\
\hline hr. & Hour \\
\hline $\mathrm{mL}$ & Millilitre \\
\hline $\mathrm{g}$ & Gram \\
\hline$\mu \mathrm{g} \mathrm{L} \mathrm{L}^{-1}$ & Microgram per litre \\
\hline $\mathrm{pH}$ & Power of hydrogen \\
\hline$\%$ & Percent \\
\hline $\mathrm{Fe}_{2} \mathrm{O}_{3}$ & Hematite \\
\hline $\mathrm{HCl}$ & Hydrochloric Acid \\
\hline $\mathrm{NaOH}$ & Sodium hydroxide \\
\hline M & Molar \\
\hline $\mathrm{Fe}$ & Iron \\
\hline ppm & Parts per million \\
\hline $\mathrm{HNO}_{3}$ & Nitric acid \\
\hline$\mu \mathrm{m}$ & Micrometre \\
\hline $\mathrm{nm}$ & Nanometre \\
\hline MHS & Mercury hydride system \\
\hline $\mathrm{ppb}$ & Parts per billion \\
\hline $\mathrm{Kg}$ & Kilogram \\
\hline $\mathrm{b}$ & Sorption system binding energy \\
\hline${ }^{\circ} \mathrm{C}$ & Celsius \\
\hline $\mathrm{Ce}$ & Concentration of equilibrium solute $\mathrm{mg} \mathrm{L}^{-1}$ \\
\hline $\mathrm{C}_{\mathrm{i}}$ & Initial arsenic concentration $\mu \mathrm{g} \mathrm{L}^{-1}$ \\
\hline $\mathrm{C}_{\mathrm{f}}$ & Final residual arsenic concentration $\mu \mathrm{g} \mathrm{L}^{-1}$ \\
\hline $\mathrm{Q}_{\mathrm{o}}$ & Langmuir constant $\mu \mathrm{g} \mathrm{g}^{-1}$ \\
\hline $\mathrm{K}$ & Mean adsorption energy constant $\mathrm{mol}^{2} \mathrm{k} \mathrm{J}^{-2}$ \\
\hline $\mathrm{Q}_{\mathrm{m}}$ & Theoretical saturation capacity $\mu \mathrm{g} \mathrm{g}^{-1}$ \\
\hline $\mathrm{E}$ & Energy $\mathrm{KJ} \mathrm{mol}^{-1}$ \\
\hline $\mathrm{q}_{\mathrm{e}}$ & Quantity of arsenic (III) adsorbed $\mathrm{mg} \mathrm{g}^{-1}$ \\
\hline $\mathrm{R}_{\mathrm{L}}$ & Separation Factor \\
\hline$\Delta \mathrm{G}^{\mathrm{o}}$ & Variation in Gibbs free energy \\
\hline$\Delta \mathrm{H}^{\mathrm{o}}$ & Change in enthalpy \\
\hline$\Delta S^{o}$ & Change in entropy \\
\hline$\varepsilon$ & Polanyi potential \\
\hline
\end{tabular}

\section{ACKNOWLEDGMENTS}

This work was supported by the Pak-US Science and Technology Cooperation Program and Higher Education Commission, Pakistan. 


\section{REFERENCES}

[1] Srivastava N.K., Majumder C. B., "Novel Biofiltration Methods for the Treatment of Heavy Metals from Industrial Wastewater", Journal of Hazardous Materials, Vol. 151, pp. 1-8, 2008.

[2] Kamde K., Dahake R., Pandey R.A., Bansiwal A., "Integrated Bio-Oxidation and Adsorptive Filtration Reactor for Removal of Arsenic from Wastewater", Environmental Technology, Vol. 40, pp. 1337-1348, 2019.

[3] Sławomir Z., "Treatment of the Processing Wastewaters Containing Heavy Metals with the Method Based on Flotation", Ecological Chemistry and Engineering, Vol. 19, pp. 433438, 2012.

[4] Fu F., Wang Q., "Removal of Heavy Metal Ions from Wastewaters: A Review", Journal of Environmental Management, Vol. 92, pp. 407-418, 2011.

[5] Hua M., Zhang S., Pan B., Zhang W., Lv L., Zhang Q., "Heavy Metal Removal from Water/Wastewater by Nanosized Metal Oxides: A Review", Journal of Hazardous Materials, Vol. 211-212, pp. 317-331, 2012.

[6] Barakat M.A., "New Trends in Removing Heavy Metals from Industrial Wastewater", Arabian Journal of Chemistry, Vol. 4, pp. 361-377, 2011.

[7] Burakov A., Galunin E., Burakova I., Kucherova A., Agarwal S., Tkachev A., "Adsorption of Heavy Metals on Conventional and Nanostructured Materials for Wastewater Treatment Purposes: A Review", Ecotoxicology and Environmental Safety, Vol. 148, pp. 702-712, 2017.

[8] Ravenscroft P., Brammer H., Richards K., "Arsenic Pollution: A Global Synthesis", John Wiley and Sons, 2009.

[9] Gomes J.A., Daida P., Kesmez M., Weir M., Moreno H., Parga J.R., "Arsenic Removal by Electrocoagulation using Combined $\mathrm{Al}-\mathrm{Fe}$ Electrode System and Characterization of Products", Journal of Hazardous Materials, Vol. 139, pp. 220-231, 2007.

[10] Wang C., Luan J., Wu C., "Metal-Organic
Frameworks for Aquatic Arsenic Removal", Water Research, 2019.

[11] Brammer H., Ravenscroft P., "Arsenic in Groundwater: A Threat to Sustainable Agriculture in South and South-East Asia", Environment International, Vol. 35, pp. 647654, 2009.

[12] Maher W., Duncan E., Martin H., Snell P., Krikowa F., Jagtap R.,"Arsenic Concentrations and Speciation in Australian and Imported Rice and Commercial Rice Products", Environmental Chemistry, Vol. 15, pp. 387-395, 2018.

[13] Podgorski J.E., Eqani S.A., Khanam T., Ullah R., Shen H., Berg M., "Extensive Arsenic Contamination in High-pH Unconfined Aquifers in The Indus Valley", Science Advances, Vol. 3, pp.1350-1358, 2017.

[14] Shakoor M.B., Niazi N.K., Bibi I., Rahman M.M., Naidu R., Dong Z., "Unraveling Health Risk and Speciation of Arsenic from Groundwater in Rural Areas of Punjab, Pakistan", International Journal of Environmental Research and Public Health, Vol. 12, pp. 12371-12390, 2015.

[15] Solangi G.S., Siyal A.A., Babar M.M., Siyal, P., "Groundwater Quality Mapping Using Geographic Information System: A Case Study of District Thatta, Sindh", Mehran University Research Journal of Engineering and Technology, Vol. 36, No. 4, pp. 10591072, Jamshoro, Pakistan, October, 2017.

[16] Bhatti Z.A., Qureshi K., Bhatti I., Unar I.N., Khuhawar M.Y., "Determination of Arsenic and Health Risk Assessment in the Ground Water of Sindh, Pakistan", Mehran University Research Journal of Engineering and Technology, Vol. 36, No. 4, pp. 10371048, Jamshoro, Pakistan, October, 2017.

[17] Mondal P., Bhowmick S., Chatterjee D., Figoli A., Van der Bruggen B., "Remediation of Inorganic Arsenic in Groundwater for Safe Water Supply: A Critical Assessment of Technological Solutions", Chemosphere, Vol. 92, pp. 157-170, 2013.

[18] Guan X.H., Wang J., Chusuei C. C., "Removal of Arsenic from Water Using Granular Ferric Hydroxide: Macroscopic and 
Microscopic Studies", Journal of Hazardous

Materials, Vol. 156, pp. 178-185, 2008.

[19] Guo X., Chen F., "Removal of Arsenic by Bead Cellulose Loaded with Iron Oxyhydroxide from Groundwater", Environmental Science and Technology, Vol. 39, pp. 6808-6818, 2005.

[20] Ahmad A., Richards L.A., Bhattacharya P., "Arsenic Remediation of Drinking Water: An Overview", Best Practice Guide on the Control of Arsenic in Drinking Water, IWA Publishing, London, Chapter-7, pp. 79-98, 2017.

[21] Leupin O.X., Hug S.J., "Oxidation and Removal Of Arsenic (III) from Aerated Groundwater by Filtration Through Sand and Zero-Valent Iron", Water Research, Vol. 39, pp. 1729-1740, 2005.

[22] Linh M., Le N.,Van H.D., Duong T., Tinh M.X., Khieu D.Q., "Adsorption of Arsenate from Aqueous Solution onto Modified Vietnamese Bentonite", Advances in Materials Science and Engineering, pp.1-13, April, 2019 .

[23] Zhu H., Jia Y., Wu X., Wang H., "Removal of Arsenic from Water by Supported Nano Zero-Valent Iron on Activated Carbon", Journal of Hazardous Materials, Vol. 172, pp. 1591-1596, 2009.

[24] Yadanaparthi S.K.R., Graybill D., Wandruszka R., "Adsorbents for the Removal of Arsenic, Cadmium, and Lead from Contaminated Waters", Journal of Hazardous Materials, Vol. 171, pp. 1-15, 2009.

[25] Guo H., Stuben D., Berner Z., Kramar U., "Adsorption of Arsenic Species from Water using Activated Siderite-Hematite Column Filters", Journal of Hazardous Materials, Vol. 151, pp. 628-635, 2008.

[26] Aredes S., Klein B., Pawlik M., "The Removal of Arsenic from Water Using Natural Iron Oxide Minerals", Journal of Cleaner Production, Vol. 29, pp. 208-213, 2012.

[27] Ali I., "Microwave Assisted Economic Synthesis of Multi Walled Carbon Nanotubes for Arsenic Species Removal in Water: Batch and Column Operations", Journal of
Molecular Liquids, Vol. 271, pp. 677-685, 2018.

[28] Agrawal P.R., Singh N., Kumari S., Dhakate S.R., "The Removal of Pentavalent Arsenic by Graphite Intercalation Compound Functionalized Carbon Foam from Contaminated Water", Journal of Hazardous Materials, 2019.

[29] Zhang Q.L., Lin Y., Chen X., Gao N.Y., "A Method for Preparing Ferric Activated Carbon Composites Adsorbents to Remove Arsenic from Drinking Water", Journal of Hazardous Materials, Vol. 148, pp. 671-678, 2007.

[30] Sahin C.A., Tokgoz I., Bektas S., "Preconcentration and Determination of Iron and Copper in Spice Samples by Cloud Point Extraction and Flow Injection Flame Atomic Absorption Spectrometry", Journal of Hazardous Materials, Vol. 181, pp. 359-365, 2010.

[31] Bhatti Z.A., "Removal of Arsenic from Drinking Water Using Indigenous Iron Ores and Modified Polyacrylonitrile as Low Cost Reactive Adsorbent Media," Ph.D. Thesis, Department of Chemical Engineering, Mehran University of Engineering and Technology, Jamshoro, Pakistan, 2018.

[32] Chatterjee S., De S., "Adsorptive Removal ff Arsenic from Groundwater Using Chemically Treated Iron Ore Slime Incorporated Mixed Matrix Hollow Fiber Membrane", Separation and Purification Technology, Vol. 179, pp. 357-368, 2017.

[33] Dhoble R.M., Maddigapu P.R., Bhole A.G., Rayalu S., "Development of Bark-Based Magnetic Iron Oxide Particle (Bmiop), A Bio-Adsorbent for Removal of Arsenic (I II) From Water", Environmental Science and Pollution Research, Vol. 25, pp. 1965719674, 2018.

[34] Yazdani M.R., Tuutijärvi T., Bhatnagar A., Vahala R., "Adsorptive Removal of Arsenic (V) from Aqueous Phase by Feldspars: Kinetics, Mechanism and Thermodynamic Aspects of Adsorption", Journal of Molecular Liquids, Vol. 214, pp. 149-156, 2016. 
[35] Glocheux Y., Pasarín M.M., Albadarin A.B., Allen S.J., Walker G.M., "Removal of Arsenic from Groundwater by Adsorption onto An Acidified Laterite By-Product", Chemical Engineering Journal, Vol. 228, pp. 565-574, 2013.

[36] Khaskheli M.I., Memon S.Q., Siyal A.N., Khuhawar MY., "Use of Orange Peel Waste for Arsenic Remediation of Drinking Water", Waste and Biomass Valorization, Vol. 2, pp. 423-433, 2011.

[37] Simsek E.B., Demircivi P., Novak I., Berek D., and Beker, U., "Novel Composite Sorbents Based on Carbon Fibers Decorated with Ferric Hydroxides-Simultaneous Removal of Antimonate and Arsenate from Aqueous Solutions", Water Supply, Vol. 19, pp. 838-845, 2019.

[38] Podder M., Majumder C., "SD/ $\mathrm{MnFe}_{2} \mathrm{O}_{4}$ Composite, a Biosorbent for As (III) and As (V) Removal from Wastewater: Optimization and Isotherm Study", Journal of Molecular Liquids, Vol. 212, pp. 382-404, 2015.

[39] Das I., Sanyal S., Ghosh K., "Environmental Chemistry, Fate and Speciation of Arsenic in Groundwater-SoilCrop Systems", Mechanisms of Arsenic Toxicity and Tolerance in Plants, pp. 361403, Springer Singapore, 2018.

[40] Mohan D., Pittman C.U., "Arsenic Removal from Water/Wastewater Using Adsorbents, a Critical Review", Journal of Hazardous Materials, Vol. 142, pp. 1-53, 2007.

[41] Ajmal M., Khan A.H., Ahmad S., Ahmad A., "Role of Sawdust in the Removal of Copper (II) from Industrial Wastes", Water Research, Vol. 32, pp. 3085-3091, 1998.

[42] Fan H.T., Sun T., Xu H.-B., Yang Y.J., Tang Q., Sun Y., "Removal of Arsenic (V) from Aqueous Solutions Using 3-[2-(2Aminoethylamino) Ethylamino] PropylTrimethoxysilane Functionalized Silica Gel Adsorbent", Desalination, Vol. 278, pp. 238243, 2011.

[43] Lv X., Huang X., Yin J., Bai, C., "Indication of the Measurement of Surface Area on Iron Ore Granulation", ISIJ International, Vol. 51, pp. 1432-1438, 2011.
[44] Elizalde-Gonz'alez M.P., Mattusch J., Einicke W.-D., Wennrich R., "Sorption on Natural Solids for Arsenic Removal", Journal of Chemical Engineering, Vol. 81, pp. 187-195, 2001.

[45] Elizalde-Gonz'alez M.P., Mattusch J., Wennrich R., Morgenstern P., "Uptake of Arsenite and Arsenate by Clinoptilolite-Rich Tuffs", Microporous and Mesoporous Materials, Vol. 46, pp. 277-286, 2001.

[46] Xu Y.-H., Nakajima T., Ohki A., “Adsorption and Removal of Arsenic (V) from Drinking Water by Aluminum- Loaded ShirasuZeolite", Journal of Hazardous Materials, Vol. 92, pp. 275-287, 2002.

[47] Mohan D., Pittman Jr., C.U., Bricka M., Smith F., Yancey B., Mohammad J., Steele P.H., Alexandre-Franco M.F., Serrano V.G., Gong H., "Sorption of Arsenic, Cadmium, and Lead by Chars Produced from Fast Pyrolysis of Wood and Bark During Bio-Oil Production", Journal of Colloid and Interface Science, Vol. 310, pp. 57-73, 2007.

[48] Thirunavukkarasu O.S., Viraraghavan T., Subramanian K.S., Tanjore S., "Organic Arsenic Removal from Drinking Water", Journal of Urban Water, Vol. 4, pp. 415-421, 2002.

[49] Badruzzaman M., Westerhoff P., Knappe, D.R.U., "Intraparticle Diffusion and Adsorption of Arsenate onto Granular Ferric Hydroxide (GFH)", Journal of Water Research, Vol. 38, pp. 4002-4012, 2004.

[50] Kundu S., Gupta A.K., "Adsorption Characteristics of As(III) from Aqueous Solution On Iron Oxide Coated Cement (IOCC)", Journal of Hazardous Materials, Vol. 142, pp. 97-104, 2007.

[51] Pierce M.L., Moore C.B., "Adsorption of Arsenite and Arsenate on Amorphous Iron Hydroxide", Water Research, Vol. 16, pp. 1247-1253, 1982.

[52] Goldberg S., "Chemical Modeling of Arsenate Adsorption on Aluminum and Iron Oxide Minerals", Journal of Soil Science Society of America, Vol. 50, pp. 1154-1157, 1986. 
[53] Haron M.J., Yunus W.M.Z., Wan Yong, N.L., Tokunaga S., "Sorption of Arsenate and Arsenate Anions by Iron (iii)-Poly (Hydroxamic Acid) Complex", Journal of Chemosphere, Vol. 39, pp. 2459-2466, 1999.

[54] Su C., Puls R.W., "Arsenate and Arsenite Removal by Zerovalent Iron: Kinetics, Redox Transformation, and Implications for in Situ Groundwater Remediation", Journal of Environmental Science and Technology, Vol. 35, pp.1487-1492, 2001.

[55] Srivastava D., Vaishya R.C., "Treatment of Arsenic (III) Contaminated Water by Dynamically Modified Iron-Coated Sand (DMICS)", Desalination and Water Treatment, Vol. 53, pp. 2565-2577, 2015.

[56] Wilkie J.A., Hering J.G., "Adsorption of Arsenic onto Hydrous Ferric Oxide: Effects of Adsorbate/Adsorbent Ratios and CoOccurring Solutes", Journal of Colloids and Surfaces, Vol. 107, pp. 97-110, 1996

[57] Lenoble V., Bouras O., Deluchat V., Serpaud B., Bollinger J.C., "Arsenic Adsorption onto Pillared Clays and Iron Oxides", Journal of Colloid and Interface Science, Vol. 255, pp. 52-58, 2002. 